\title{
Dr. Arthanari and Dr. Nisar reply
}

\section{To the Editor:}

In response to Dr. Rooney's comments, as described in our report ${ }^{1}$, the right knee relapsed during the course of our patient's second pregnancy, leading to the diagnosis of tubercular monoarthritis. During this pregnancy the arthritis of the peripheral small joints was, as expected, in remission. Thus there was no indication of Poncet's disease.

At the time of diagnosis, acid-fast bacillus was isolated from earlymorning urine samples, suggesting the primary source of infection was the urinary tract. Although symptomatic, no structural damage was found. Our patient had no gastrointestinal symptoms, so invasive investigations were not justified. Glandular tuberculosis is the most common extrapulmonary manifestation in the South Asian population and is of much greater significance than the gastrointestinal tract 2,3 .

We did consider the possibility of corticosteroid injection being a contributory factor. However, while such joint injections are common, there is no evidence in the literature of this procedure resulting in local tubercular infection. We did also consider the role of pregnancy in promoting articular tuberculosis, but again there is no definitive evidence to support this. In contrast, our case illustrates the potential for an underlying arthropathy ${ }^{4}$ and local damage, irrespective of cause, to predispose to such infection ${ }^{5-7}$.

SUBHA ARTHANARI, MRCP(UK), Staff Grade Medical Officer;

MOHAMED NISAR, FRCP(UK), Consultant Rheumatologist, Department of Rheumatology, Queen's Hospital, Burton Hospital NHS Trust, Burton on Trent DE130RB, United Kingdom. Address reprint requests to Dr. M.

Nisar. E-mail: mohamed.nisar@burtonh-tr.wmids.nhs.uk

\section{REFERENCES}

1. Arthanari S, Yusuf S, Nisar M. Tuberculosis of the knee complicating seronegative arthritis [letter]. J Rheumatol 2008;35:1227-8.

2. Sreeramareddy CT, Panduru KV, Verma SC, Joshi HS, Bates MN. Comparison of pulmonary and extrapulmonary tuberculosis in Nepal - a hospital-based retrospective study. BMC Infect Dis 2008;8:8.

3. Nisar M, Williams CS, Davies PD. Experience of tuberculosis in immigrants from South East Asia - implications for the imminent leaseback of Hong Kong. Respir Med 1991;85:219-22.

4. Bryan WJ, Doherty JH Jr, Sculco TP. Tuberculosis in a rheumatoid patient. A case report. Clin Orthop Relat Res 1982;171:206-8.

5. Varango G, Bamba I, Kodo M, Dao A, Lambin Y. Osteonecrosis of the hip in sickle cell disease associated with tubercular arthritis. A review of 15 cases. Int Orthop 1998;22:384-9.

6. Pointud P, Prudat M, Laluque S, Amaroux J. Tuberculous arthritis and chondrocalcinosis. Apropos of 2 cases. Rev Rheum Ed Fr 1993;60:617-20.

7. Ferris BD, Goldie B, Weir W. An unusual presentation of tuberculosis — 'injury TB'. Injury 1987;18:347-9.

J Rheumatol 2009;36:1; doi:10.3899/jrheum.080849 